\title{
Fish Kill Incidents and Harmful Algal Blooms in Omani Waters
}

\author{
Hamed Mohammed Al Gheilani ${ }^{1 *}$, Kazumi Matsuoka², \\ Abdulaziz Yahya AlKindi ${ }^{3}$, Shehla Amer ${ }^{4}$, and Colin Waring ${ }^{5}$
}

${ }^{1}$ Ministry of Agriculture and Fisheries Wealth,

P.O. Box 427, PC 100, Muscat, Sultanate of Oman

2Institute for East China Sea Research, Nagasaki University,

1-14 Bunkyo-machi, Nagasaki, 852-8521, Japan

${ }^{3}$ Department of Biology, College of Science, Sultan Qaboos University,

P.O. Box 36, PC 123 Al Khodh, Sultanate of Oman

${ }^{4}$ Nizwa University, Sultanate of Oman

${ }^{5}$ Marine Institute, Portsmouth University, United Kingdom

\begin{abstract}
حـوادث نفـوق الأسـماك وازدهار الطحـالب الضـارة في المياه العـمانيـة

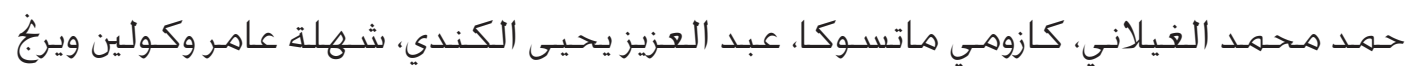

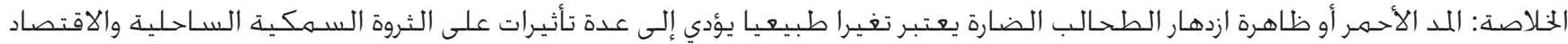

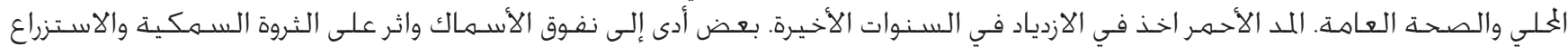

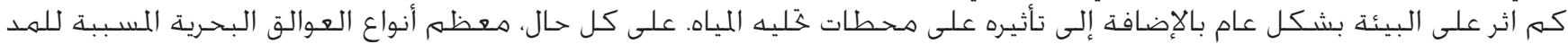

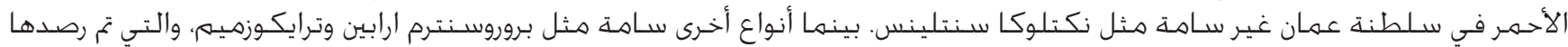

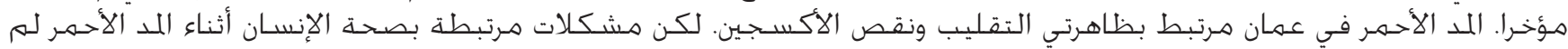
تسجل في عمان.
\end{abstract}

ABSTRACT: Red tide, one of the harmful algal blooms (HABs) is a natural ecological phenomenon and often this event is accompanied by severe impacts on coastal resources, local economies, and public health. The occurrence of red tides has become more frequent in Omani waters in recent years. Some of them caused fish kill, damaged fishery resources and mariculture, threatened the marine environment and the osmosis membranes of desalination plants. However, a number of them have been harmless. The most common dinoflagellate Noctiluca scintillans is associated with the red tide events in Omani waters. Toxic species like Karenia selliformis, Prorocentrum arabianum, and Trichodesmium erythraeum have also been reported recently. Although red tides in Oman have been considered a consequence of upwelling in the summer season (May to September), recent phytoplankton outbreaks in Oman are not restricted to summer. Frequent algal blooms have been reported during winter (December to March). HABs may have contributed to hypoxia and/or other negative ecological impacts.

Keywords: Red tide, HABs, fish kill, Noctiluca scintillans, phytoplankton, upwelling, hypoxia.

\section{Introduction}

Throughout the world's coastal waters, harmful algal bloom are being reported with increasing frequency and causing severe impacts on coastal resources, local economies and public health. Harmful algal blooms (HABs) are caused by microalgae, usually single-celled prokaryotic and eukaryotic photosynthetic organisms that live in freshwater, estuarine and marine realms. Harmful and toxic incidents caused by dinoflagellates are intensifying and spreading all over the world accompanied with extensive ecological damage during the last four decades (Cho, 1981; Olsen et al., 1988; Smayda and Fofonoff, 1989; Chen and Gu, 1993; Hallegraeff, 1993; Nuzziet al., 1996; Anderson, 1997; Wong, 1989; Kim et al.,1990, 1993; Steidinger, 1993) including the coastal waters of Oman (Thangaraja et al., 1990, 1991, 1998, 2000, 2007; Al Gheilani et al., 2005, 2007; Al Kindi et al., 2007, unpublished; Al Busaidi et al., 2008; Richlen et al., 2010; Matsouka et al., in preparation). The reasons for the increasing red tides may be related to the global climate change, increase of human impact in coastal zones, awareness resulting from scientific research and reports of HABs events.

The negative effects caused by such micro-algae include the biotoxins, physical damage and the anoxia or hypoxia (Al Gheilani et al., 2005). However, cell densities of causative micro-algae cannot increase forever and as soon as the first critical nutrient runs out, the bloom will collapse 


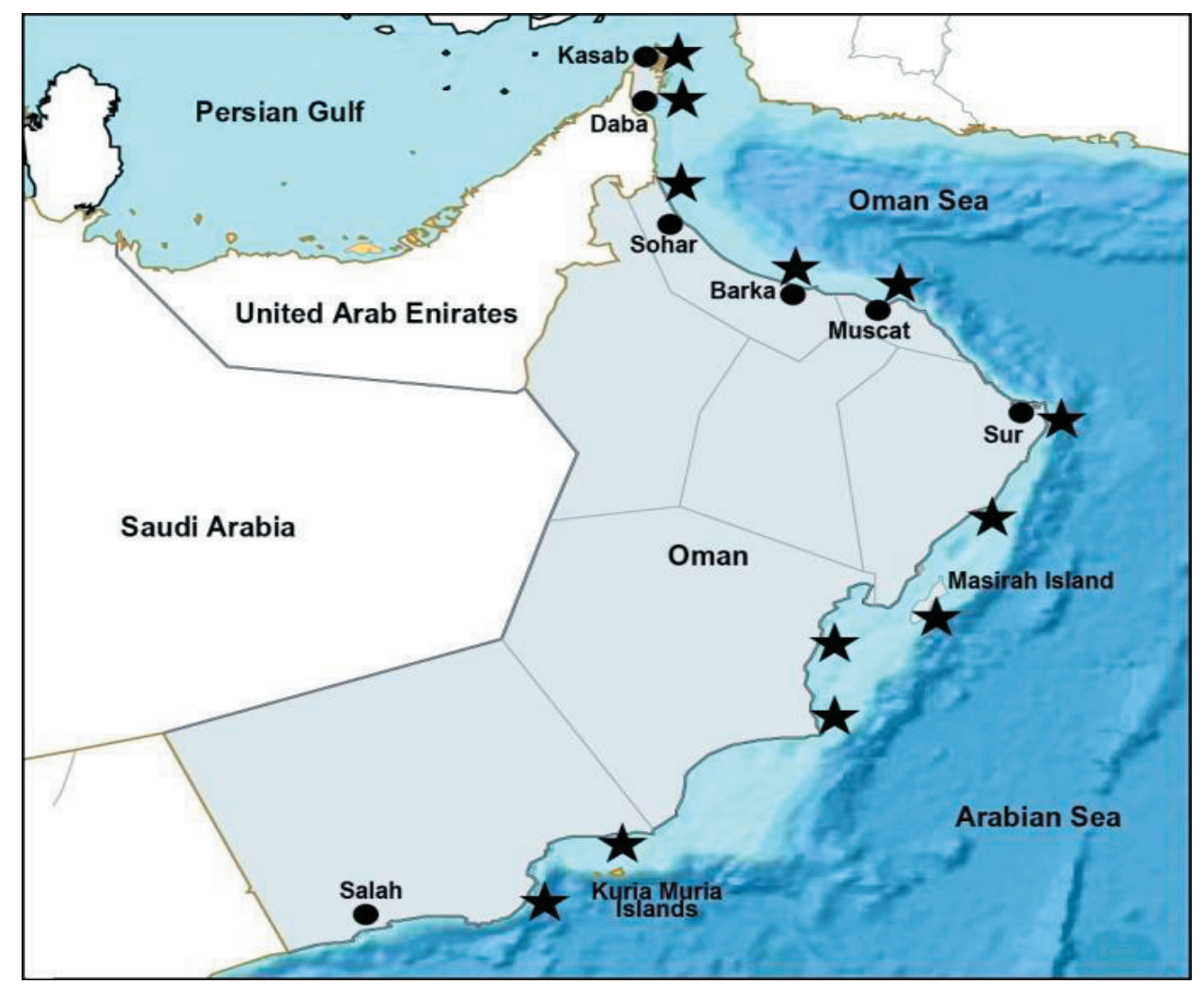

Figure 1. Distribution of red tide in Omani coast.

(Van den Bergh et al., 2002). Thus, for understanding $\mathrm{HAB}$ phenomena the behavior of nutrients is one of the important subjects for research.

Since HABs are globally distributed and integral parts of marine and brackish-water ecosystems, the main research problems can be addressed comprehensively and effectively only through international, interdisciplinary and comparative research on important questions about the dynamics of HABs within their oceanographic and ecological systems (GEOHAB, 1998). Recurring algal blooms and red tides in the coastal waters of Oman have been documented for nearly three decades, and some of them cause damage to the marine environment and economic losses to the fisheries industry. The other negative effects of red tides-causing dinoflagellates in Omani waters include the production of biotoxins, physiological damages to fish and the anoxia or hypoxia in the environment (Al Gheilani et al., 2005). Hence, in order to diminish fisheries damages, especially for aquaculture, adequate monitoring systems of the outbreaks are required. As HABs are of national concern to Oman, there is need to foster national cooperative research on HABs in order to find better solutions regarding this issue.

This paper intends to provide an overview of HABs history, causative species and previous research activities for establishing counter measures to HABs damages in the Sultanate of Oman.

\section{History of HAB Occurrences and Investigations in Oman}

Early scientific records of red tide events in Oman prior to 1976 were rare. The first HAB / red tide incident was reported during the $4^{\text {th }}$ week of August 1976 along the Salalah coast between Taqah and Raysut, and caused a loss of about 7,000-10,000 tons of fish (Barwani, 1976, unpublished report). Subsequently, there were two more incidents of mass mortality of fish in Muscat; one in October 1976 and the other in February 1978, and causative organisms were N. scintillans and Gonyaulax sp. (Zahran, 1978), respectively. Since 1988, there has been regular documentation and monitoring of red tides and their impacts on the coastal waters of Oman (Thangaraja, 1990, 1991; Thangaraja et al., 1998, 2000, 2007; Al Gheilani et al., 2010, unpublished). Different coastal regions of Oman show variation in susceptibility to algal blooms and red tides, however most of the incidents have been recorded from the Muscat region (Fig. 1). The red tides appear to have become more widespread and persistent since late 1980s (Fig. 2).

A review of different HABs occurrences from 1976 to 2009 showed that about 81 red tide events have been recorded along the coastal waters of Oman; of which 10 incidents have resulted in mass mortality of fish and other marine organisms (Figs. 2 and 3; Table 1). 


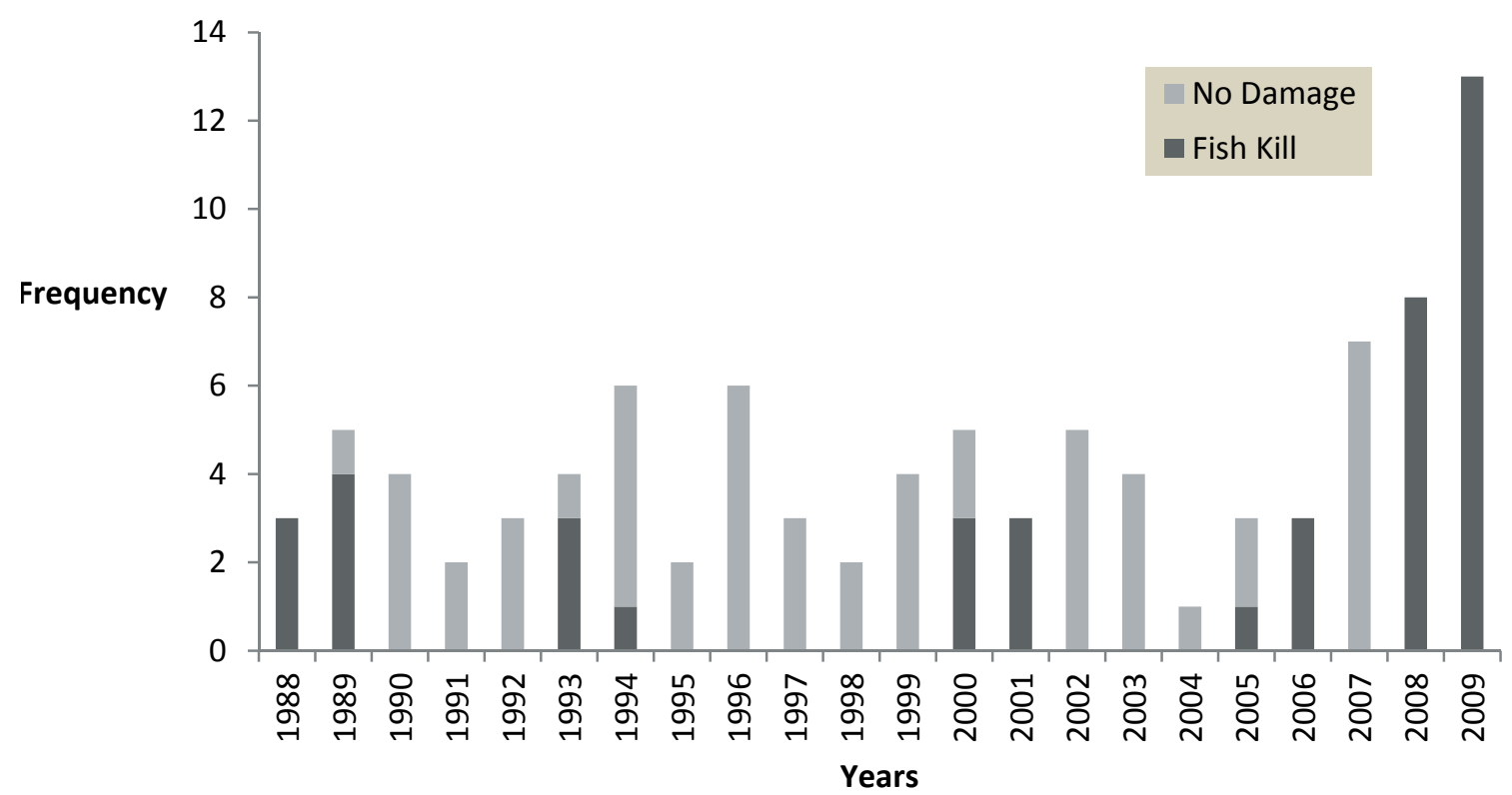

Figure 2. Major HABs event occurring in Oman (70) and HABs outbreaks causing fisheries damage and marine organism mortalities (22) (Data: Ministry of Fisheries Wealth).

Of the 22 identified HABs causative species, 16 were dinoflagellates and most of the fish kills were caused by these dinoflagellates (Thangaraja et al., 2000, unpublished report of The Ministry of Agriculture and Fisheries Wealth). Red tide data (Thangaraja et al., 2000, data from Ministry of Agriculture and Fisheries; Al Gheilani et al., unpublished) showed that $80 \%$ of all identified algal blooms were caused by dinoflagellates singly or in combination with diatoms. Noctiluca scintillans is the most important species causing more than $50 \%$ of HABs in Omani waters, but most Noctiluca blooms (31 from 37 blooms) did not affect marine organisms.

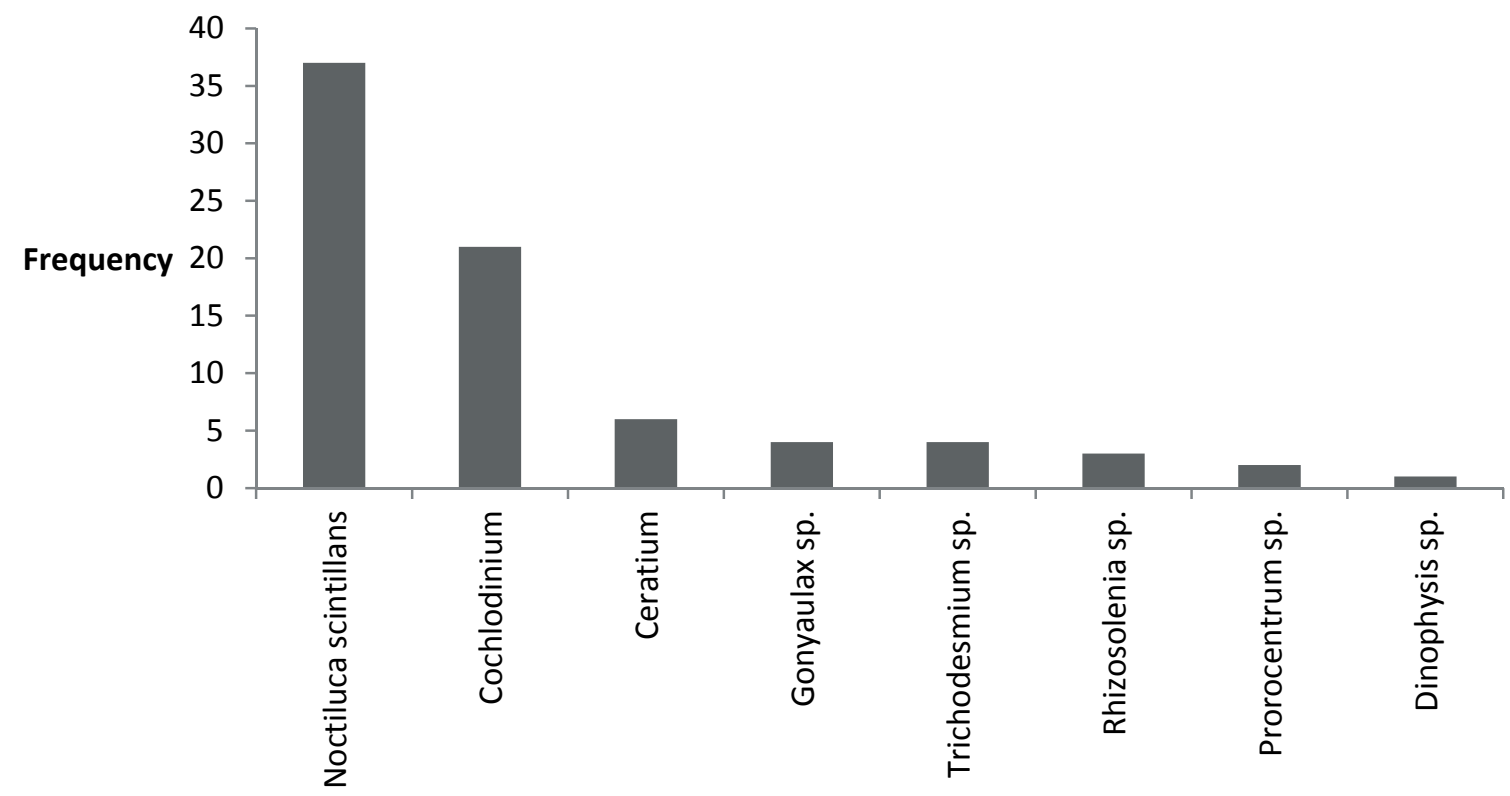

Phytoplankton Species

Figure 3. Main $\mathrm{HABs}$ causing species in Omani waters. 
Table 1. Massive fish kills recorded in Omani waters (1976-2009).

\begin{tabular}{|c|c|c|c|}
\hline Period & Major Species & Area & Mortality \\
\hline August 1976 & - & Salalah & $7000-1000$ tons of fish \\
\hline September 1988 & $\begin{array}{l}\text { Ceratium fucus } \\
\text { C. macroceros } \\
\text { Diatom }\end{array}$ & Seeb to Qurum & $\begin{array}{l}\text { Mass mortality of marine } \\
\text { organisms }\end{array}$ \\
\hline August to September 2000 & Coscinodiscus spp & Barka & $15-30$ tons of fish \\
\hline March 2001 & - & Sur & 250 tons of fish \\
\hline April 2001 & - & Al Sharqiya & 34 tons \\
\hline November to December 2001 & - & $\begin{array}{l}\text { Al Sharqiya and Al } \\
\text { Wasta }\end{array}$ & $\begin{array}{l}40 \text { tons of fish } \\
250 \text { turtles }\end{array}$ \\
\hline January 2004 & - & Bander Kharan & 3000 tuna fish \\
\hline October 2005 & $\begin{array}{l}\text { Noctiluca scintillans; Prorocentrum } \\
\text { micans and Trichodesmium erythraeum }\end{array}$ & Masirah & Massive fish Kill \\
\hline September 2006 & - & Sohar & Massive fish kill \\
\hline October 2008 to April 2009 & Cochlodinium polykrikoides & Oman and Arabian Sea & 200 tons of fish and shellfish \\
\hline
\end{tabular}

\section{Mechanism of Algal Blooms in Oman}

For intensive fish mass mortality in Oman, the following two scenarios are possible; 1) depletion of dissolved oxygen, and/or 2) blooms of toxic phytoplankton species.

\section{Oxygen depletion}

The phenomenon of oxygen depletion is increasing in coastal waters of the world (Kamykowski and Zentara, 1990) with occurrence as permanent, seasonal and episodic features. Oxygen depletion in the waters can result in hypoxic or anoxic conditions in the coastal areas. Two principal factors that lead to the development of hypoxia and anoxia; 1) water column stratification that isolates the bottom water from exchange with oxygenrich surface water and followed by 2) decomposition of organic matter in the isolated bottom water that reduces oxygen levels (Sarmiento et al., 1988; Diaz, 2002).

Persistent low oxygen is evident in oxygen minimum zones (OMZ) defined as regions where oxygen concentrations are $<0.5 \mathrm{ml}^{*} \mathrm{l}^{-1} \quad(22 \mu \mathrm{M}$; Levin, 2003). The OMZ in the Northern Arabian Sea impinges on the continental margin creating permanently hypoxic conditions in the deep coastal to baythal benthic environment (Reichart, et al., 2002). On the Oman continental margin, the OMZ extends down from about $60 \mathrm{~m}$ to about $1000 \mathrm{~m}$ deep, with gradual increasing dissolved oxygen (DO) below this depth to "normal" near saturated oxygen levels by 2000-2500m (Lamont and Gage, 2000). Bacterial oxidation in sinking organic matter typically found just below the thermocline at the depth from 50 to $100 \mathrm{~m}$ (Morrison et al., 1999) brings highly fertile conditions for growth of phytoplankton and other photosynthetic organisms in the northern Arabian Sea and the Oman Sea. Consequently, the Arabian Sea has one of the thickest oxygen depleted layers of ocean water found anywhere in the world (Gooday et al., 2000; Herring, 2002). Sometimes, due to shifts in the overlying wind field, these deep oxygen-poor waters upwell to the surface indirectly leading to periodic mass fish kills.

In the Arabian Sea the differences in oxygen concentrations between the mixed layer, thermocline and deep waters become most apparent during periods of strong thermal stratification (at the end of the summer) when mixing across the thermocline is nearly impossible. The mixed layer has temperatures ranging from 25 to $32^{\circ} \mathrm{C}$ and high $\mathrm{DO}$ content $\left(\mathrm{DO}=4 \mathrm{mll}^{-1}\right.$ to $6 \mathrm{ml} \mathrm{l}^{-1}$ or higher). The temperature of the thermocline is between $24^{\circ} \mathrm{C}$ and $26^{\circ} \mathrm{C}$ and the DO concentrations are between $2 \mathrm{ml} \mathrm{l}^{-1}$ and $4 \mathrm{ml} \mathrm{l}^{-1}$, while the deeper water has temperature below $24^{\circ} \mathrm{C}$ and DO concentrations below $2 \mathrm{mll}^{-1}$ (Morrison et al., 1999).

The breakdown of stratification of water column occurs in periods of upwelling (cold water brought to the surface) and either relaxation or downwellings (surface water pushed down along the coast). During the upwelling, water masses transported from 60 or $70 \mathrm{~m}$ depth result in the lowering of the temperature to $23-25{ }^{\circ} \mathrm{C}$ at the sea surface. These cool waters are also poor in oxygen but rich in nutrients. This nutrient rich water is then susceptible to 
Table 2. Species causing HABs in Omani waters and their effects.

\begin{tabular}{|c|c|c|}
\hline & $\begin{array}{l}\text { Number. of } \\
\text { Occurrences }\end{array}$ & Impact \\
\hline \multicolumn{3}{|l|}{ Single Species } \\
\hline Noctiluca scintillans & 37 & $\begin{array}{l}\text { Fish mortality (6) } \\
\text { No damage (31) }\end{array}$ \\
\hline Cochlodinium polykrikoides & 21 & Fish and shellfish mortality (21) \\
\hline Ceratium sp. & 06 & $\begin{array}{l}\text { Fish mortality (3) } \\
\text { No damage (3) }\end{array}$ \\
\hline Rhizosolenia sp. & 03 & No damage \\
\hline Trichodesmium sp. & 04 & $\begin{array}{l}\text { Fish mortality (1) } \\
\text { No damage (3) }\end{array}$ \\
\hline Gonyaulax polygramma & 04 & Fish mortality (4) \\
\hline Prorocentrum sp. & 02 & No damage \\
\hline Coscinodiscus & 01 & Fish mortality \\
\hline Karenia mikimotoi & 01 & No damage \\
\hline \multicolumn{3}{|l|}{ Mixed Species } \\
\hline Gonyaulax, Noctiluca & 02 & Fish mortality (2) \\
\hline C. fusus, C. macroceros, diatoms & 01 & Fish mortality \\
\hline $\begin{array}{l}\text { N. scintillans, C.furca, C. macroceros, P. micans, Pyrophacus } \\
\text { holorogicum, Peridinium }\end{array}$ & 01 & No damage \\
\hline $\begin{array}{l}\text { Rhizosolenia, Pleurosigma sp., Nitzschia pungens, Coscinodiscus } \\
\text { spp., Fragilaria sp., Triceratium sp., Chaetoceros sp., Ceratium sp. }\end{array}$ & 01 & No mortality \\
\hline $\begin{array}{l}\text { Coscinodiscus marginalis, Asteromptelus spp., Chaetoceros sp., } \\
\text { Rhizosolenia sp., Ceratium sp. }\end{array}$ & 01 & No mortality \\
\hline Dinophysis, Ceratium spp. & 01 & Fish mortality \\
\hline $\begin{array}{l}\text { N. pungens, Rhizisolenia alata, Thalassisora, Cyclotela, Pyrocystis, } \\
\text { Gymnodium splendens, P. minimum, P. arabianum }\end{array}$ & 01 & Fish, green turtle and bird mortality \\
\hline
\end{tabular}

trigger the development of phytoplankton bloom (mostly harmless diatoms), at least for the few days that follow the onset of upwelling. Savidge and Gilpin (1999) estimated chlorophyll $a$ concentrations and primary production to be maximal in the coastal upwelling zone in N W Indian Ocean during the late monsoon season. After a rapid growth, the phytoplankton produce oxygen at least in the upper layers of the water column, but during night they consume oxygen. Later in the cycle, the nutrient cannot sustain any further growth of the phytoplankton and dead or dying cells start to sink or decay. In bacterial denitrification, nitrate ions are used for oxidation of organic matter, in this process they are reduced to molecular nitrogen with nitrite as an intermediate (Codispoti and Christansen, 1989). Nitrification, the oxidation of nitrite and ammonium also occurs in these waters (Ward et al., 1989).
The low oxygen condition physiologically stressful for fish usually varies among taxa. The point at which various animals suffocate varies, but generally effects start to appear when oxygen drops below $2 \mathrm{ml} \mathrm{l}^{-1}$ or 2.8 $\mathrm{mg} \mathrm{l}^{-1}$, for seawater, this is about $18 \%$ saturation (Diaz and Rosenberg, 1995).

In several parts of the world, fish kills have been attributed to low dissolved oxygen levels generated by high biomass blooms and not necessarily due to toxicity. For example, from 1980-1989, at least 50\% of fish kill in the Gulf of Mexico and 69\% in the South Atlantic, USA, were attributed to low dissolved oxygen (Lowe, et al., 1991). Similarly, the low DO levels have caused fish mortality in Oman.

In most cases the dominant red tide causative species in the Oman Sea is N. scintillans (Table 2). 


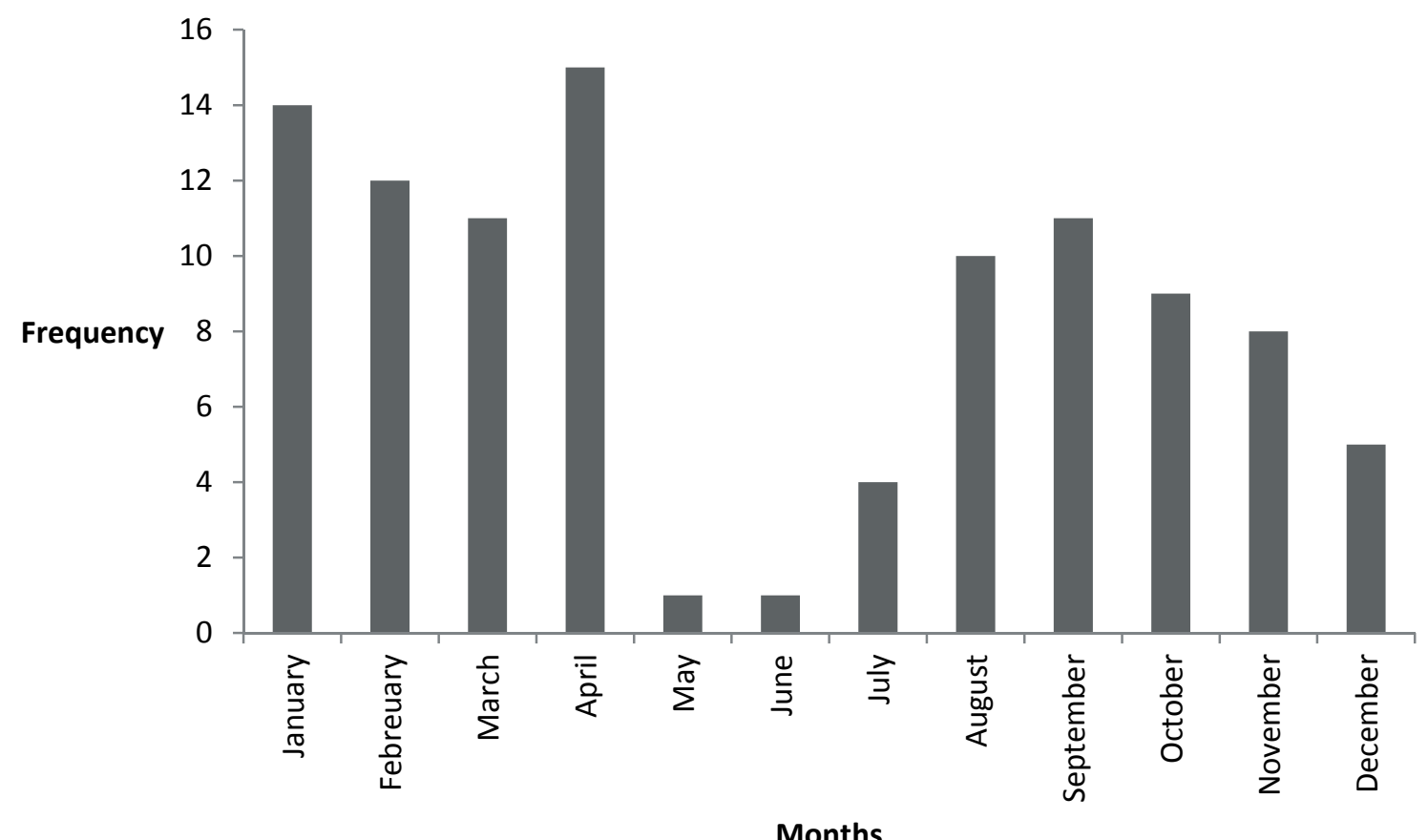

Figure 4. Seasonal variation of HABs in Omani waters.

The appearance of $N$. scintillans was noted in plankton samples collected within the waters of Muscat from $1^{\text {st }}$ February till the end of March 1988 (Thangaraja, 1990). At that time red tide of this species was recorded along the coast of the Oman Sea from Khasab to Sur. N. scintillans produced many patches of orange red coloration in the waters from Al-Bustan to Qurum on $1^{\text {st }}, 8^{\text {th }}$, and $10^{\text {th }}$ February with a peak on the $19^{\text {th }}$ March, 1988 . This species formed red tide blooms almost every year in the Oman Sea between January and May since 1988 (Thangaraja, 1990). The bloom intensity of $N$. scintillans is increasing year by year. In 1999 a new strain of this species formed green tide in the eastern coasts in the Oman Sea (MSFC, 19762010).

Phytoplankton blooms were also observed three times between February 1988 and April 1989 along the

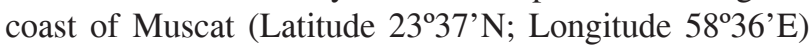
(Thangaraja et al.,1990). Blooms occurring from $5^{\text {th }}$ to $20^{\text {th }}$ of September 1988 (with a peak on the $14^{\text {th }}$ ) caused discoloration of waters from Seeb to Qurum, and mass mortality of marine organisms happened in a $30 \mathrm{~km}$ coastal stretch. The dinoflagellates identified were Ceratium fusus, C. macroceros, C. furca, Prorocentrum micans, Pyrophacus horologicum and Protoperidinium species. However, excepting C. fusus, the other dinoflagellates were few in number. Large blooms of these organisms caused first discoloration of the water and then mass mortality of marine life. Low oxygen levels were recorded $(2.64 \mathrm{ml} / \mathrm{l}$ and $1.87 \mathrm{ml} / \mathrm{l})$ at water depths of 2-3 meters and 8-10 meters respectively, on $14^{\text {th }}$ September 1988 at Al-
Ghubrah coast. Seawater temperature was $27.5^{\circ} \mathrm{C}$, salinity $35.9 \%$ and $\mathrm{pH}$ 8.31-9.0 (Thangaraja, 1990). Although, Ceratium spp. are not toxic, they are known to cause deterioration of the water quality (Onoue, 1990).

$N$. scintillans blooms repeatedly appeared in the Muscat coasts in the plankton samples from $25^{\text {th }}$ February to $5^{\text {th }}$ April 1989. Dense patches of discoloration were noticed about $5 \mathrm{~km}$ off shore on $5^{\text {th }}$ April during the regular plankton survey. On $11^{\text {th }}$ April the bloom developed denser than that of the previous year, the intensity of red tide started declining on $12^{\text {th }}$ April. Between $11^{\text {th }}$ and $13^{\text {th }}$ April, eight species of dead fish were found at Al-Bustan coast during this bloom. This was a significant record of fish kills by $N$. scintillans bloom (Thangaraja, 1990). Previous data suggest that in Oman no red tide was noticed in the summer season but these events are common in winter months including January and February (Fig. 4).

It was observed that $N$. scintillans bloom affected marine ecosystems in two different ways; first depletion of oxygen and then bacterial infection. According to Thangaraja (1990), in the first incident of fish kill during February to March 1988 both above-mentioned effects were recognized, but in 1989 only the depletion of oxygen was observed. The dead fish collected during 1989 bloom showed no morphological abnormalities of gills or gill clogging. The guts were in advanced stages of putrefaction and therefore their contents were not examined. Thousands of the pelagic fish, Atherinomorus lacunosus were killed with "fin and tail rot" disease caused by bacterial infection following the Noctiluca bloom 
(Thangaraja, 1990). There are several examples which show that either acute/chronic exposure to microalgal toxins or harmful mechanisms associated with HABs was sufficient to increase the susceptibility of aquatic organisms to disease. During 1989-1990, a N. scintillans bloom in the Pie Hai Sea (Northern China Sea) resulted in losses of about $\$ 100$ millions in shrimp Penaeusorientalis mariculture. Poor water quality caused an increase in the susceptibility of prawns to parasitic infections, which led to disease mortalities and additional losses valued at \$I million (Chen and Gu, 1993).

Most of the HABs-related fish mortality events in Oman have been attributed to Noctiluca blooms (Table 2). Accumulated ammonia is produced after death, and dissolution of Noctiluca cells caused fish mortalities (Schaumann, et al., 1988, Okaichi and Nishio, 1976, Suvapepun, 1989). When the bloom of Noctiluca at maximum cell densities of $5.3 \times 10^{6} \mathrm{~m}^{3}$ occurred accompanied with a mass mortality of demersal fish and benthic organisms along the east coast of Jakarta Bay of Indonesia in July 1986, ammonia, nitrogen and phosphate levels in the seawater just after the mortality were significantly increased (Adnan, 1989). In some cases, such conditions may not result in mortality but in avoidance by fish, leading to localized reductions in fisheries. Noctiluca can also create a large quantity of mucus, which mechanically damages fish gills or interferes with fish respiration (Subramanian, 1985). Thus large blooms of heterotrophic Noctiluca can consume significant amounts of oxygen and after their subsequent decay bacterial production can result in severe oxygen depletion. Therefore, although not considered toxic, large Noctiluca blooms can significantly contribute to deterioration of water quality, accompanied with depleted dissolved oxygen (Elbrachter and Qi, 1998; Subramanian, 1985; Suvapepun, 1989; Ho and Hodgkiss, 1992).

Another major incident of phytoplankton blooms was reported in Oman along Seeb Al-Hail shores approximately $10 \mathrm{~km}$ from Muscat during the second week of August 2000. In the last week of August 2000, another incident of fish kill was reported in Barka, some $80 \mathrm{~km}$ from Muscat. It was the consequence of a series of local upwelling of oxygen poor waters with DO levels measuring less than 1-2ppm (Mathews et al., 2001). Analysis of water samples taken from the area revealed that large centric diatoms of the genus Coscinodiscus were responsible for the bloom (Claereboudt et al., 2001). However, this genus is known not to contain toxic species for the moment. Non-toxic Coscinodiscus caused depletion of oxygen in already oxygen poor waters (Claereboudt et al., 2001). DO concentrations were found to be $2.6 \mathrm{mg} / \mathrm{l}$ at $5 \mathrm{~m}$ depth and $0.40 \mathrm{mg} / \mathrm{l}$ at $10 \mathrm{~m}$ depth (Thangaraja et al., 2000). Analyses of nutrients off coastal waters along Dhofar coasts showed that the waters had become eutrophic with nutrient levels in excess of $20 \mu \mathrm{M}$ nitrate-nitrogen and $2 \mu \mathrm{M}$ phosphatephosphorous found between July and mid October 2000 (Savidge et al., 1990). High levels of nutrients and low temperature $\left(<20^{\circ} \mathrm{C}\right)$ accounted for dense blooms of phytoplankton (maximum $>20 \mu \mathrm{g}$ chlorophyll a $\mathrm{l}^{-1}$ ) and the annual development of dense beds of macroalgae along the Arabian Sea coasts (Savidge et al., 1990). As Malcolm et al. (1999) also suggested that during the monsoon season, upwelling is the major influence on the nutrient supply in the surface waters of the Arabian Sea off the coast of Oman, high nutrient such as levels of $\mathrm{NO}_{3}\left(=18 \mu \mathrm{mol} \mathrm{l}{ }^{-1}\right)$ and $\mathrm{PO}_{4}\left(1.48 \mu \mathrm{moll}^{-1}\right)$ in the close inshore coastal zone and also higher concentrations $\left(\mathrm{NO}_{3}=12.5 \mu \mathrm{moll}^{-1} ; \mathrm{PO}_{4}=\right.$ $\left.1.2 \mu \mathrm{moll}^{-1}\right)$ at the region of offshore upwelling off the shelf during September/October 1994.

\section{Toxic Algal Blooms in Oman and Their Impact}

The abnormal production of phytoplankton (diatoms, dinoflagellates and blue green algae) such as Trichodesmium sp., Dinophysis spp., Gonyaulax spp., and Ceratiums pp. led to discolouration of water and caused either environmental impacts or mass mortality of marine organisms in Omani waters in 2000 (Thangaraja et al., 2000). A total 109 fish species were recorded as causative organisms for massive fish kills. These species consists of the coral reef associated fish species (59\%), demersal fish species inhabiting shallow coastal waters (28\%), and pelagic species (13\%) (Claereboudt et al., 2001).

The upwelling of nutrients in SW monsoon triggered blooms in March-April and November-December 2001. As a result of these HABs, widespread fish and green turtle (Cheloniamydas) mortalities appeared in the Southern region of Oman. About 284 tons of fish during March and April and 40 tons of fish along with 250 turtles, some dolphins and birds were killed during November and December, 2001 (MAF and MRMEWR, 2002). The taxonomic composition of the bloom showed that the bloom was dominated by diatom Nitzschia pungens Grunow ex Cleve(=Pseudo-nitzschia pungens (Grunow ex Cleve) Hasle), N. cf. subcurvata Hasle (Pseudonitzschiasubcurvata (Hasle) Fryxell), Rhizosolenia alata Brightwell (=Proboscia alata (Brightwell) Suderstom, Thalassiosira spp., and Cyclotellaspp. (Stirn et al., 1993). The secondary succession phase appeared to be dominated by dinoflagellate such as Pyrocystis sp., and potentially toxic dinoflagellates Gymnodium splendens Lebour(=Akasahio sanguinea (Hirasaka) G. Hansen et Moestrup) and Prorocentrum minimum (Pavillard) (Garrison et al., 1998). An unarmored ichtyo-toxic dinoflagellates Karenia selliformis Haywood, Steidinger et MacKenzie originally described from New Zealand in 2004 first occurred in water samples collected from the north and south of Khaluf in concentrations of 2,492,000 cells/liter [Drs. J. Landberg, K. Steidinger and A. Haywood at the Florida Marine Research Institute, St. Petersburg, Florida, U.S.A. (preliminary unpublished report, 2005)]. $K$. selliformis is phylogenetically related to $K$. mikimoto $i$ (Miyake and Kominami) G. Hansen et Moestrup and $K$. brevis (Davis) G. Hansen et Moestrup (Haywood et al., 2004). Other species such as K. mikimotoi and Karenia 
digitata Yang, Takayama, occurring in Hong Kong during March and April 1998 killed fish worth US \$40,000,000 (Lu and Hodgkiss, 2004). Although Karenia spp. including K. mikimotoi has reportedly caused mass fish mortality in Kuwait Bay (Heil et al., 2001; Gilbert et al., 2002), it is not unknown in the Arabian Sea. The toxins produced and released by these microorganisms might be responsible for the mortality of green turtles, dolphins and birds in Oman (Jupp, 2001).

Moreover, a new species of planktonic dinoflagellate, Prorocentrum arabianum was recorded during this incident in 2001 and was added to the list of hazardous species, because $P$. arabianum was capable of producing a cytotoxic as well as an ichthyotoxic compound (Morton et al., 2002).

After the major fish and marine organism mortality event in 2001, nine other red tide incidents were recorded in 2002 and six incidents were recorded in 2003. $N$. scintillans was identified as red tide causative species in all cases except for one. K. mikimotoi was found in the plankton samples from bloom in March 2003. However, none of these blooms caused any damage to fisheries or other marine organisms (unpublished data, Ministry of Agriculture and Fisheries). In 2004, five algal blooms were recorded and $N$. scintillans was probably responsible for all blooms. Fish mortality was observed in three of these incidents occurring in January, April and September 2004 (unpublished report of Ministry of Agriculture and Fisheries Wealth).

Recently, at the end of October 2005, extensive blooms occurred in the east of Masirah Island accompanied with massive fish mortality. This HABs event lasted for eight days accompanied by a red-orange discolouration of the water. Hydrographical surveys using satellite images revealed low temperatures due to upwelling of waters with oxygen deficient. Plankton analysis revealed $N$. scintillans, Prorocentrum micans and toxic blooms of cyanobacteria Trichodesmium erythraeum (Ehrenberg) (Al Busaidi et al., 2008). More recently, in August 2006, massive fish kills occurred in Muscat. Depletion of oxygen was suspected to be the reason of the demersal fish kill. Also, in September 2006, a massive fish kill occurred in Sohar. The levels of oxygen were within the normal range. No harmful species were reported, but the water temperature was lower than the usual condition (Ministry of Agriculture and Fisheries, 2006). No fish kill were recorded in 2007. However, extremely large fish kills were recorded in 2008-2009 caused by blooms of Cochlodinium polykrikoides. The blooms were started in the Oman Sea in September 2008 in Musandam and Al Batinah Coasts and ended in April 2009 in the Arabian Sea and the Oman Sea. More than 200 tons of fish and shellfish were killed. During these blooms, seventy tons of Goldlined seabream were killed at an aquaculture farm in Quraiat, Muscat. The levels of oxygen were very low (less than $1 \mathrm{mg} / \mathrm{l}$ ) during Cochlodinium blooms. As well as the low oxygen levels during Cochlodinium blooms, damage to fish gills were also recorded (Richlen et al.,
2010; Matsoukaet al., unpublished; Al Gheilani et al., unpublished).

These HABs events occur on a regular basis in Oman and require a long-term solution.

\section{Conclusion}

A programme for the establishment of a HABs monitoring system was launched in the Sultanate of Oman in 1978. The system deals with monitoring of environmental conditions, including studies on red tides, and collection of data on the taxonomy of marine biota, hydrology and water quality. Meteorological and oceanographic data including current, temperature, oxygen, algae and nutrients are obtained on a regular basis from different sites and positions along the coastal waters of Oman. However, the quality of technology for detecting, modeling and predicting harmful algal blooms needs improvement. Modeling of bloom-forming mechanisms of various causative organisms are tried in order to create a prediction system. Unfortunately, this has not been very effective mostly because of incomplete data acquisition and accumulation. Water quality data collection and reporting are not consistent among different agencies, reducing the effectiveness of the data for modeling of bloom-forming mechanisms. Spatial and temporal monitoring of harmful algal blooms continue in Oman and research is being conducted that will assist in management of the blooms. Scientists and managers are making efforts to create less cumbersome, cheaper, faster and automated detection techniques, which would greatly benefit them in responding to these events more efficiently and effectively. However, vigorous efforts need to be devoted to the elucidation of the biology and ecology of red tide organisms and their blooming mechanisms, modeling and mitigation methods in the Sultanate. Since Oman has a large mariculture operation, future research efforts need to be focused on the influence of mariculture activity in triggering $\mathrm{HAB}$ occurrences in coastal areas to help retain a healthy marine ecosystem along the coast of Oman. Hence, there is also an urgent need for bloom mitigation strategies in aquaculture areas in the Sultanate.

\section{Acknowledgements}

We are grateful to the staff, scientists and researchers of the Marine Science and Fisheries Center, Ministry of Agriculture and Fisheries Wealth, Sultanate of Oman, for providing the data of red tides in Oman.

\section{References}

Adnan, Q. 1989. Red tides due to Noctiluca scintillans (MacCartney) Ehrenb, and mass mortality of fish in Jakarta Bay. In: Red Tides, Biology, Environmental Science and Toxicology, T.D. Okaichi, D.M. Anderson, and T. Nemoto (Editors), 53-55. Elsevier, New York.

Al Busaidi, S.S., K.M. Al Rashdi, H.M. Al Gheilani, and S. Amer.2008. Hydrographical observations during 
red tide with fish mortalities at Masirah Island, Oman. Sultan Qaboos University Agricultural and Marine Sciences - A Research Journal 13:65-73.

Al Ghelani, H.M., A.Y.A. AlKindi, S.Amer, and Y.K. Al-Akhzami. 2005. Harmful algal blooms: Physiology, behavior, population dynamics and global impacts - A review. Sultan Qaboos Univeresity Journal for Science 10:1-30.

Al Ghelani, H.M. 2007. Physiological and biochemical effects of hypoxia exposure on Goldlinedseabream, Rhabdosargussarba. $\mathrm{PhD}$ thesis. University of Portsmouth, UK.

Al Kindi, A.Y.A., H.M.H. Al Gheilani, S. Amer, and Y.K. Al-Akhzami. 2007. Action plan for monitoring, mitigation and management of Harmful algae blooms in the coastal waters of Oman. Sultan Qaboos University Journal for Science 12:75-85.

Anderson, D.M. 1997. Bloom dynamics of toxic Alexandrium species in the Northeastern United States. Limnology and Oceanography 42:1009-1022.

Chen, Y.Q. and X.G. Gu. 1993. An Ecological Study of Red tides in the East China Sea. In: Toxic Phytoplankton Blooms in the Sea, T.J. Smayda and Y. Shimizu (Editors), 223-228. Elsevier, Amsterdam.

Cho, C.H. 1981. On the Gymnodium red tide in Jinhae Bay. Bulletin of the Korean Fisheries Society 14:227-232.

Claereboudt, M., G. Hermosa, and E. McLean. 2001. Plausible cause of massive fish kills in the Gulf of Oman. In: Proceedings of the $1^{\text {st }}$ International Conference on Fisheries, Aquaculture and Environment in the NW Indian Ocean, M. Claerboudt, S. Goddard, H. Al-Oufi, and J. McIlwain (Editors), 123-132. Sultan Qaboos University, Muscat, Sultanate of Oman.

Codispoti, L.A. and J.P. Christiansen. 1989. Nitrification, denitrification and nitrous oxide cycling in the eastern tropical South Pacific Ocean. Marine Chemistry 16: 277-300.

Diaz, R.J. and R. Rosenberg. 1995. Marine benthic hypoxia: A review of its ecological effects and the behavioural responses of benthic macrofauna. Oceanography and Marine Biology: An Annual Review 33:245-303

Diaz, R.J. 2002.Hypoxia and anoxia as global phenomena. In: Fish Physiology, Toxicology, and Water Quality. Proceedings of the $6^{\text {th }}$ International Symposium, R.V. Thurston (Editor), 183-201. La Paz, B.C.S., Mexico.

Elbrachter, M. and Y.Z. Qi. 1998. Aspects of Noctiluca(Dinophyceae) Population Dynamics. In: Physiological Ecology of Harmful Algal Blooms, D.M. Anderson, A.D. Cembella, and G.M. Hallegraeff(Editors), 31-35. Springer-Verlag, Heidelberg.

Garrison, D.L., M.M. Gowing, and M.P. Hughes. 1998. Nano and micro plankton in the northern Arabian Sea during the Southwest Monsoon, August-September, 1995: AUSJGOFS Study. Deep Sea Research II 45: 2269-2299.
GEOHAB, 1998. Global Eology and Oceanography of Harmful Algal blooms. A plan for coordinated scientific research and co-operation to develop, international capabilities for assessment, prediction and mitigation.Report from a Joint IOC/SCOR Workshop, Havreholm, Denmark.

Gilbert, P.M., J.H. Landsberg, J.J. Evans, M.A. Al-Sarawi, M. Faraj, M.A. Al-Jarallah, A. Haywood, S. Ibrahim, P. Kelsius, C. Powel, and C. Shoemaker. 2002. A fish kill of massive proportion in Kuwait Bay, Arabian Gulf, 2001: The role of bacterial disease, harmful algae and eutrophication. Harmful Algae 1:215-231.

Gooday, A.J., J.M. Bernhard, L.A. Levin, and S.B. Suhr. 2000. Foraminefera in the Arabian Sea oxygen minimum and the other oxygen deficient settings: taxonomic composition diversity, and relates to metazoan faunas. Deep Sea Research II 47:25-54.

Hallegraeff, G.M. 1993. A review of harmful algal blooms and their apparent global increase. Phycologia 32:7999.

Haywood, J.A., K.A. Steidinger, E.W. Truby, P.R. Bergquist, P.L. Bergquist, J. Adamson, and L. Mackenzie. 2004. Comparative morphology and molecular phylogenetic analysis of three new species of the genus Karenia (Dinophyceae) from New Zealand. Journal of Phycology 40:165-179.

Heil, C.A., P.M. Gilbert, M.A. Al-Sarawi, M. Faraj, M. Behbehani, and M. Husain. 2001. First record of a fishkilling Gymnodium sp. bloom in Kuwait Bay, Arabian Sea: chronology and potential causes. Marine Ecology Progress Series 214:15-23.

Herring, D. 2002. Fish kill in the Gulf of Oman -a space based diagnosis. Web site of NASA (http://earthobserv atory.nasa.gov/Study/oman/).

Ho, K.C. and I.J. Hodgkiss. 1992. Severe Fishkill in Hong Kong Caused by Noctiluca scintillans. Red Tide Newsletter 5:1-12.

Jupp, B.P. 2001. Report on Fish and Turtle Mortalities on Sharquiyah and Al-Wusta Coast, Field Trip, 22-25 Dec. 2001. 16 pp.

Kamykowski, D. and S.J. Zentara. 1990. Hypoxia in the world ocean as recorded in the historical data set. DeepSea Research II 37:1861-1874.

Kim, H.G., J.S. Park, and S.G. Lee. 1990. Coastal Algal Blooms Caused by the Cyst Forming Dinoflagellates. Bulletin of the Korean Fisheries Society 23:468-474.

Kim, H.G., J.S. Park, Y. Fukuyo, H. Takayama, K.H. An, and J.M. Shim. 1993. Noxious Dinoflagellate Bloom of an Undescribed Species of Gyrodinium in Chumgmu Coastal Waters, Korea. In: Harmful Marine Algal Blooms, P. Lassus, G. Arzul, E. Erard, P. Gentien, and C. Marcaillou (Editors), 59-63. Lavoiser, Intercept Limited, Paris; New York.

Lamont, P.A. and G.D. Gage. 2000. Morphological responses of macrobenthicpolychaetes to low oxygen on the Oman continental slope, NW Arabian Sea. DeepSea Research II 47:9-24. 
Levin, L.A. 2003. Oxygen minimum zone benthos: Adaptation and community response to hypoxia. Oceanography and Marine Biology: An Annual Review, 41:1-45.

Lowe, J.A., D.R.G. Farrow, A.S. Pait, S.J. Arenstam, and E.J. Lavan. 1991. Fish Kills in Coastal Waters 1980-1989. National Oceanographic and Atmospheric Administration. 69pp.

MAF and MRMEWR. 2002. Project proposal for the development of a draft action plan for marine monitoring in relation to mass marine mortalities in Oman. Ministry of Agriculture and Fisheries and Ministry of Regional Municipalities, Environment and Water Resources, Sultanate of Oman.

MAF. 2006. Annual Report. Ministry of Agriculture and Fisheries, Sultanate of Oman.

Malcolm, E., S. Woodward, A.P. Rees, and J.A. Stephens. 1999. The influence of the south- west monsoon upon the nutrient geobiochemistry of the Arabian Sea. DeepSea Research II 46:571-591.

MSFC 1976-2010. Marine Science and Fisheries Center Annual Reports, 1976-2010. MSFC, Sultanate of Oman.

Mathews, C.P., J. Al-Mamary, and J. Al-Belushi. 2001. Impacts of upwelling, red tides and related oceanographic events on the fisheries of Muscat, Batinah and Oman. Ministry of Agriculture and Fisheries Report, 17pp.

Morrison, J.M., J.M. Codispoti, S.L. Smith, K. Wishner, C. Flagg, W.D. Gardner, S. Gaurin, S.W.A. Naqvi, V. Manghanani, L. Prosperie, and J.S. Gunderson. 1999. The oxygen minimum zone in the Arabian Sea during 1995. Deep Sea Research II 46: 903-1931.

Morton, S.L., M.A. Faust, E.A. Fairey, and P.D.R. Moeller. 2002. Morphology and toxicology of Prorocentrum arabianum sp.nov., (Dinophyceae) a toxic planktonic dinoflagellate from the Gulf of Oman, Arabian Sea. Harmful Algae 1:393-400.

Nuzzi, R., P. Olsen, J.B. Mahoney, and G. Zodl. 1996. The First Aureococcus anophagefferens Brown Tide in New Jersey. Harmful Algae News 15:8-9.

Okaichi, T. and S. Nishio. 1976. Identification of Ammonia in the Toxic Principle of Red Tide of Noctiluca scintillan. Bulletin of the Plankton Society of Japan 23:75-80.

Olsen, M.S., P. Olsen, J.B. Mahoney, and E. Feerst. 1988. Occurrence of the Dinoflagellate Gonyaulax tamarensis, in New Jersey. Bulletin of the New Jersey Academy of Science 33:45-49.

Onoue, Y. 1990. Massive Fish Kills by a Ceratium fusus Red Tide in Kagoshima Bay, Japan. Red Tide Newsletter 3:2.

Reichart, G.J., S.J. Schenau, G.J. deLange, and W.J. Zachariasse. 2002. Synchroneity of oxygen minimum zone intensity of the Oman and Pakistan margins at sub-Milankovitch time scales. Marine Geology 185: 403-415.
Richlen, M. L., S.L. Morton, E.A. Jamali, A. Rajan, and D.M. Anderson. 2010. The catastrophic 2008-2009 red tide in the Arabian Gulf Region, with observations on the idenrification and phylogeny of the fish-killing dinoflagellate Cochlodinium polykrikoides. Harmful Algae 9:163-172.

Sarmiento, J.L., T.D. Herbert, and J.R. Toggweiler. 1988. The Influence of Some Hydrographical Factors on the Fisheries of the Cochin Area. Bulletin of the National Institute of Sciences of India 38:846-853.

Savidge, G., H.J. Lennon, and A.D. Mathews. 1990. A shore based survey of upwelling along the coast of Dhofar region, Southern Oman. Continental Shelf Research 10:259-275.

Savidge, G. and L. Gilpin. 1999. Seasonal influences on size-fractionated chlorophyll $a$ concentrations and primary production in the northwest Indian Ocean. Deep-Sea Research II 46:701-723.

Schaumann, K., D. Gerdes, and K.J. Hesse. 1988. Hydrographic and biological characteristics of a Noctiluca scintillans red tide in the German Bight. Meeresforsch 32:72-91.

Smayda, T.J. and P. Fofonoff. 1989. An extraordinary, noxious brown-tide in Narragansett Bay. II. Inimical effects. In: Red Tides: Biology, Environmental Science and Toxicology, S.T. Okaichi, D.M. Anderson, and T. Nemoto (Editors), 133-136. Elsevier, New York.

Steidinger, K.A. 1993. Some taxonomic and biological aspects of toxic dinoflagellates. In: Algal Toxins in Seafood and Drinking Water, I.R. Falconer, (Editor), 1-28. London Academic Press.

Stirn, J., H. Al-Habsi, R. Hunt, M. Sideek, and J. Villanueva. 1993. Initial stage of upwelling in the Arabian Sea concomitant phytoplankton blooms and euphotic layer hypoxia. Preliminary Results of R.V. Mitchell Cruise in the ROPME Sea Area, pp 175192. ROPME/IOC (UNESCO/UNEP) NOAA/EPC (Kuwait).

Subramanian, A. 1985.A Noxious Dinoflagellate in Indian Waters. In: Toxic Dinoflagellate, D.M. Anderson, A.W. White, and D.G. Baden (Editors), 525-528. New York: Elsevier.

Suvapepun, S. 1989. Occurrences of Red Tide in the Gulf of Thailand. In: Red Tides, Biology, Environmental Science and Toxicology, T. Okaichi, D.M. Anderson, and T. Nemoto (Editors), 41-44. New York: Elsevier.

Thangaraja, M. 1990. Studies on red tides off Oman. MSFC Research Report Number 90-2. Ministry of Agriculture and Fisheries. Sultanate of Oman. 25pp.

Thangaraja, M. 1991. Phytoplankton bloom -Indicator of sardine fisheries. MSFC Research Brief Number 911. Ministry of Agriculture and Fisheries. Sultanate of Oman. 9pp.

Thangaraja, M., A. Al Aisry, and L. Al Kharusi. 1998. Report on the incidents of phytoplankton blooms, red tide phenomena, toxic species involved and their impacts in Omani waters. MSFC Research Report 
Number 98-1. Ministry of Agriculture and Fisheries. Sultanate of Oman. 52pp.

Thangaraja, M., A. Al-Aisry, L. Al-Kharusi, and H.A. Al-Shaqsi. 2000. Phytoplankton blooms, red tide phenomena and recorded impacts in Oman. MSFC Annual Report. Ministry of Agriculture and Fisheries, Sultanate of Oman. 22pp.

Thangaraja, M., A. Al-Aisry, and L. Al-Kharusi. 2007. Harmful algal blooms and their impacts in the middle and outer ROPME sea area. International Journal of Oceans and Oceanography 2:85-98.

Van den Bergh, J.C., P.A. Nunes, H.M. Dotinga, W.H. Kooistra, E.G. Vrieling, and L. Peperzak. 2002. Exotic harmful algae in marine ecosystems: an integrated biological-economic-legal analysis of impacts and policies. Marine Policy 26:59-74.
Ward, B.B., H.E. Glover, and F. Lipschultz. 1989. Chemoautotrophic activity and nitrification in the oxygen minimum zone off Peru. Deep-Sea Research 36:1031-1051.

Wong, P.S. 1989. The occurrence and distribution of red tides in Hong Kong - applications in the red tide management. In: Red Tides Biology, Environmental Science and Toxicology. Proceedings of the $1^{\text {st }}$ International Symposium on Red Tides, Japan, 1987, S.T. Okaichi, D.M. Anderson, and T. Nemoto (Editors), 125-128. Elsevier, New York, Amsterdam, London.

Zahran, T. 1978. Red tide. AlMawared Al Tabei'eiah, (June, 1978 issue), 19-20.

Received: November 28, 2010

Accepted: September 4, 2011 